\title{
Investigating the Implementation of Online Learning in Remote Learning Context
}

\author{
Dwi Tahamata Nyudak ${ }^{*}$, I Nyoman Adi Jaya Putra ${ }^{2}$, Made Hery Santosa ${ }^{3}$
}

1,2,3 English Language Education, Post Graduate Program, Universitas Pendidikan Ganesha, Singaraja, Indonesia

\section{A R T I CLE I N F O}

Article history:

Received March 04, 2021

Revised March 05, 2021

Accepted April 24, 2021

Available online May 25, 2021

Kata Kunci :

Pembelajaran Online, Konteks

Pembelajaran Jarak Jauh

Keywords:

Online Learning, Remote Learning Context

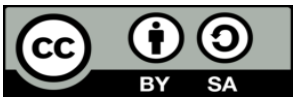

This is an open access article under the CC BY-SA license.

Copyright (C) 2021 by Author. Published by Universitas Pendidikan Ganesha

\begin{abstract}
A B S T RAK
Covid-19 membawa banyak perubahan di bidang pendidikan terutama pada peran TIK yang sering digunakan untuk mendukung pembelajaran akhir-akhir ini. Namun, bahkan tanpa pandemi ini, agen pengajar sebenarnya harus perlahan menyesuaikan cara pembelajaran dilakukan sejak pembelajaran abad ke-21 dan revolusi industri 4.0 menekankan poin penting tentang penggunaan TIK untuk pembelajaran selain 4C (Komunikasi, Kolaborasi, Kreativitas, dan Berpikir Kritis). Penelitian ini bertujuan untuk menganalisis kognisi guru terhadap pembelajaran online; pelaksanaan pembelajaran online; konsistensi kognisi guru dan pelaksanaan pembelajaran online; persepsi guru terhadap online; persepsi siswa terhadap pembelajaran online; dan persepsi orang tua terhadap pembelajaran online. Dalam pengumpulan data dilakukan analisis kuesioner, wawancara dan observasi. Hasil penelitian menunjukkan bahwa guru memiliki kognisi yang tinggi terhadap pembelajaran online; guru melakukan beberapa persiapan dan ada beberapa prosedur yang diterapkan dalam pembelajaran online dalam konteks pembelajaran jarak jauh; kognisi guru dan implementasinya konsisten; guru mempersepsikan pembelajaran online secara positif; siswa mempersepsikan pembelajaran online secara positif dengan beberapa informasi mengejutkan dari kuesioner terbuka yang berada di sisi yang berbeda dari kuesioner tertutup; orang tua menganggap pembelajaran online dalam pandangan yang seimbang pada awalnya tetapi kuesioner terbuka berdiri di sisi negatif.
\end{abstract}

\section{A B S T R A C T}

Covid-19 brings many changes in educational field especially on the role of ICT which is frequently used to support learning recently. However, even without this pandemic, teaching agents actually should slowly adjust the way learning is done since $21^{\text {st }}$ century learning and industrial revolution 4.0 bold important point on the use of ICT for learning besides the 4Cs (Communication, Collaboration, Creativity and Critical thinking). This study aims to analyze teacher's cognition towards online learning; the implementation of online learning; the consistency of teacher's cognition and implementation of online learning; teacher's perception toward online; students' perception toward online learning; and parents' perception toward online learning. In collecting the data, questionnaires, interview and observation checklist analysis were done. The result showed that the teacher had high cognition towards online learning; the teacher did several preparations and there were some procedures applied in online learning in remote learning context; teacher's cognition and the implementation were consistent; the teacher perceived online learning positively; the students perceived online learning positively with some surprising information from the open-ended questionnaire which was in different side from the closed ended questionnaire; the parents perceived online learning in a balance view at first but the open-ended questionnaire stood on negative side.

\section{INTRODUCTION}

Corona Virus Disease or Covid-19 has become the biggest issue nowadays (Gustiani, 2020; Suryaman et al., 2020). It is no longer endemic or even epidemic because it is already pandemic since Covid-19 has infected many people all over the world. The spread of this virus is really quick and make almost many governments in many countries apply social distancing, physical distancing and stay at home policies. Therefore, since Corona Virus pandemic has infected many people in the world, it impacts many sectors including education. Since the suggestion for social, physical distancing and stay at home policy are applied, Covid-19 has changed and influenced many aspects of this world including economic, cultural as well as educational sector (Demertzis et al., 2020; Putri et al., 2020). For educational sector itself, the existence of this pandemic brings many changes especially on how learning should be done. Besides, work from home (WFH) and study from home (SFH) regulation are also applied due to Covid-19 pandemic. 
Related to study from home due to prevention to Covid-19, government suggests educational agents to conduct the learning through Learning Platforms known as Learning Management System (LMS) (Rasmitadila, Widyasari, et al., 2020; Sit \& Brudzinski, 2017). It means that learning process is totally done at home through learning platform is also called as remote learning or online learning. There are many learning platforms supporting online learning in this remote learning context. Those are Moodle, Schoology, Edmodo, Blackboard, Quipper School, Google Classroom or even in WhatsApp and Facebook. During recent situation, there is no choice for the schools in Indonesia to teach the students except through remote learning only (Kristiawan et al., 2021). Fortunately, the development of technology nowadays is great which can support the learning process to be done maximally. There are many positive impacts given by the development of technology for education (Ahmadi, 2018; Bhattacharjee \& Deb, 2016; Ghavifekr \& Rosdy, 2016; R. M. Hernandez, 2014; Ronald M. Hernandez, 2017; Lin et al., 2017; Pankaj S. Parsania, 2015; Parvin \& Salam, 2018; Saeed, 2015). The role of ICT in education starts becoming vital since there is a massive development of technology recently. It is recognized that it supports both teacher and students. It is not only helpful for administration purpose only but also for teaching and learning process such as by integrating games and activities involving gadgets like computer and smartphone in which those are useful to attract students' attention and motivation to learn in school (Bhattacharjee \& Deb, 2016; Ghavifekr \& Rosdy, 2016; Kaffash et al., 2010; Pankaj S. Parsania, 2015).

Indeed, Covid-19 brings many changes in educational field especially on the role of ICT which is frequently used to support learning recently. However, even without this pandemic, teaching agents actually should slowly adjust the way learning is done since $21^{\text {st }}$ century learning and industrial revolution 4.0 bold important point on the use of ICT for learning besides the 4Cs (Communication, Collaboration, Creativity and Critical thinking). Moreover, teachers should realize the difference in characteristics of students from year to year because it will never be the same. The existence of technology in education or EdTech gives more options for teachers to vary their teaching and learning strategies in order to be able to deal with today's generation. Thus, there are many strategies, learning material as well as learning tools that can be used to make an effective teaching and learning to meet recent students' expectation. The digital revolution brings the transformation to some particular fields including sociology, culture, technology, economy, and education (Çevikbaş \& Argün, 2017). All field has transformed in this time as a result of industrial revolution. Education is one of some aspects that changes in which the students is no longer the same as the previous generation, the method of teaching must also be varied to meet their expectation as well as to maintain their motivation and engagement in learning to achieve the demand of education nowadays (Çevikbaş \& Argün, 2017). It is found that low motivation is one of among other factors that makes learning English difficult, especially in writing (Fareed \& Bilal, 2016). Then, to reach the expectation, the role of teacher in class becomes more challenging since the teacher need to catch up with technology which becomes one aspect that students like in this era (Kumar et al., 2008).

In the academic year 2019/2020, the students are no longer Generation Y, but they are already Generation Z (Afrilyasanti et al., 2017; Arnold-Gaza, 2014; Çevikbaş \& Argün, 2017). This Generation is also referred as Generation I, Digital Natives, Post Millennial and Generation Z in which they were born and come to this life with technology already by their side (Santosa, 2017). The one that distinguishes them from the previous generation is they have close relation with electronic things and digital world such as internet, web, smart phone and laptop. Thus, it can be labelled that technology is their identity (Csobanka, 2016; Singh \& Dangmei, 2016). In relation to education, education and all things related to education have new roles in which motivation, effective teaching method should be well organized. In addition, the new role of teacher is also important to support the new generation (Csobanka, 2016). Hence, today's learning process should be adjusted to suit the need of students nowadays. However, online learning also gives good result and advantages. Distance learning is great idea but there are some aspects which need to be focused on such as motivation, time management and technical things (Owens et al., 2009). There is no issues related to the use of technology since the participants are common to technology but if there is one who is not familiar with tools for online learning, it may cause less confident for joining remote learning. In some cases, internet connection must be issues for anyone. On the other side, online learning gives free space and time to access the material in which it is good since the learning is flexible. Remote learning also saves significant amoount of money (Rahman et al., 2015; Sadeghi, 2019; Traxler, 2018).

The use of online learning during this Covid-19 pandemic is good idea especially since it supports $21^{\text {st }}$ century learning and industrial revolution 4.0 which suggests to use ICT-based learning to suit students' characteristics. Nevertheless, the problem now refers to teacher's competence and readiness toward ICT whether the teacher is skilful and ready enough to utilize and implement ICT for remote learning during this pandemic. Some researchers have conducted researches on difficulties or issues faced 
by teacher in using ICT in all over the world. The results show that indeed, teachers find it difficult to deal with technology whether it is caused by lack of training, competence or influenced by their attitude toward ICT in which the teachers are reluctant to adapt themselves with development of ICT because they feel ICT slows down their effectiveness for designing learning materials (Ghavifekr et al., 2016; Habibu et al., 2012; Suryani, 2010). The teachers also think that they do not have enough time to learn about ICT; the time is limited. In conclusion, the recent condition forms a new way of learning which may give impact to all participants. Therefore, their perceptions are important to be observed especially about online learning in remote learning context nowadays. Based on some considerations above especially related to online learning during Remote Learning Context and the role of ICT as well as their issues during this Covid-19 pandemic, research on those topics seems good since it is happening nowadays. Therefore, this research will identify teacher's cognition towards online learning during remote learning context (related to ICT as well) and the implementation of remote learning during this Covid-19 pandemic. Those topics (cognition and implementation of online learning) are planned to be investigated in order to know the consistency of teacher's cognition in online learning as well as the implementation of it. Advantages and disadvantages during the implementation were also analyzed especially from the viewpoint of students, teachers and parents since students are now at home and education is done at home.

\section{METHODS}

Since the study utilized mixed method as the research methodology, the research design taken was explanatory mixed method research design in which it was one of some types of research designs for mixed method research (Creswell, 2012; Schoonenboom \& Johnson, 2017). The data were mixed of quantitative and qualitative put primarily on quantitative data. The subjects of recent study were a teacher, 30 students (one intact class) at SMP Negeri 5 Mengwi and 10 parents. Purposive sampling technique was used to select the subjects. The students chosen as the subject are third-grade students. 10 parents chosen randomly in this research by which their child was also the sample of this study. Besides, a teacher chosen as a sample was an English teacher which is already a magister of education graduated from Ganesha University of Education. The teacher was 26 years old and he has been teaching at SMPN 5 Mengwi since 2016. The teacher had also passed PPG program in 2020.

Since the study utilized qualitative research design, there were several kinds of instruments used for data collection which were developed from some theories, namely questionnaire, observation sheet, interview guide and check list. Data were gathered through different instruments, namely questionnaire, observation, interview guide and checklist. First, questionnaire is administered to the teacher related to his cognition in ICT use and online learning in Remote Learning context. Interview guide was used to get data for the second research question in which it identified the implementation of online learning during remote learning context like kinds of activities, assignments, steps as well as kind of feedback given to students. In addition, Observation was also conducted to get more data. After the data for cognition and implementation was collected, consistency between cognition and the implementation are measured through checklist. Moreover, the next research questions in which about perception were gathered by using questionnaires in which it identified perception from different viewpoints such as from teachers, students and parents which is related to online learning in remote learning context.

For the data analysis in recent mixed method study, sequential quantitative-qualitative and quantitative-dominant mixed analysis was applied. Sequential quantitative-qualitative analysis means quantitative data analysis was conducted earlier and followed by qualitative data analysis (Morse \& Niehaus, 2009; Onwuegbuzie \& Combs, 2011; Schoonenboom \& Johnson, 2017). The first research question is analyzed through ideal mean score analysis and categorize into certain levels to identify cognition level of the teacher. For the second research question, interactive data analysis is used since the data is gathered through interview and observation. In addition, the third research question is analyzed through descriptive quantitative. Besides, the fourth, fifth and sixth research questions are also analyzed by using ideal mean score but those were also analyzed through interactive data analysis since the instruments contain both quantitative and qualitative data

\section{RESULT AND DISCUSSION}

\section{Results}

Since the process of teaching and learning is done separately in which it is online learning in a certain Learning Management System (LMS), the research investigated teacher's cognition toward online learning. The participant selected as the source of data was an English teacher. The data were collected 
through questionnaire which consisted of 25 statements covering knowledge, self-efficacy and belief in dealing with ICT tools, LMS, internet, online gaming platform and apps used to conduct synchronous learning by utilizing teleconference apps. Based on the analysis, Xmax was the maximum score that the teacher could get if the answer was all 5 or strongly agree and the Xmin was the minimum score that the teacher could get from the questionnaire if the answer was all 1 as it referred to strongly disagree. Since there were 25 items included and it used Likert-scale point in which it was 1-5 representing strongly disagree until strongly agree at 5 point, so the minimum score or Xmin was 25 and the possible maximum score was 125. Range, Mean Ideal (MI) and Standard Deviation Ideal (SDI) was analyzed in order be able to categorize the level of teacher's cognition.

The result of categorization of teacher's cognition toward online learning. After the categorization of level was made, the next step was to figure out the level of cognition of the teacher whether it was low, moderate or high cognition. The teacher got 113 from the questionnaire in which it referred to high level of cognition because it was above 91.7 as the minimum score for high level of cognition toward online learning. Therefore, it could be identified that the teacher had very good knowledge, self-efficacy and belief in dealing with ICT tools, LMS, internet, online gaming platform and apps used to conduct synchronous learning by utilizing teleconference apps. By having high cognition level toward online learning, the implementation of online learning must have been good as how cognition level of teacher was.

\section{The Implementation of Online Learning in Remote Learning Context}

There were two instruments used to collect the data namely interview guide as well as observation sheet. Interview was done earlier to identify the implementation of online learning by the teacher from the preparation until the plan for the implementation which was then followed by observing phase during the online learning process. The teacher's understanding toward online learning was kind of learning done separately between teacher and students. The way the teacher decided the learning goals was by looking at the syllabus as the guidance to make the lesson plan. Synchronous and asynchronous apperception was done to make sure that the students realized the learning goals of the lesson. There were some stages applied by the teacher for online learning in remote learning context. Figure 3 was the example of stages or syntax applied by the teacher to organize the class. For the learning platform used by the teacher in online learning, Google Classroom was used and also web meeting apps like google meet was used to give apperception at the beginning of the lesson. The materials prepared by the teacher were varied. There was power point, module, podcast, self-made video and also video from YouTube. Figure 2 was example of media and material given by the teacher for online learning.

The activities and assignment were usually given in a period of time because so the students could do the assignment properly since there was a difference on students' competence. When the material was shared in Google Classroom, the students were given like the whole 1 day to access the material and follow the instruction given if there were any things to do related to the materials. The reason was because sometimes the students used one smartphone with their parents whereas most of their parents worked in the morning. Therefore, one day access was given to students. To make sure the students activeness, the teacher monitored the discussion section, the present list in each day lesson was given as well as the assignments. There were two evaluation prepared by the teacher in the implementation of online learning namely knowledge and skill evaluation. Based on the interview, the time spent to prepare the online learning was approximately one week. From the interview data, it could be seen that the teacher has a planned syntax in conducting online learning with the students which could be seen on Figure 1. The teacher also used web meeting via google meet to start the apperception section which was then continued with the syntax planned and the materials prepared for each lesson. Since the students were now Gen Z, the teacher also prepared various learning materials like module, Power Point Presentation as well as videos. Besides the teacher monitored students' activeness through discussion section and the assignment submitted by the students. In addition, it was noted that the time needed to prepare the online learning materials was one week.

To enrich the data related to the implementation of online learning in remote learning context, observation sheet was used. There were several points observed through observation sheet to enrich the data. The ICT tools used by the teacher in online learning were varied. In some moment, the teacher used smartphone to access Google Classroom. However, computer and laptop were the tools used the most by the teacher in conducting online learning. For example, when the Wi-Fi connection was not stable in school computer or laptop, the teacher used his smartphone to meet students in a web meeting through Google Meet. There were several Learning Management System available but Google Classroom was used because the school had decided that all teacher should use Google Classroom. Synchronous online learning was also conducted by the teacher in which learning was done at the same time in a time which had been 
decided before. Besides, synchronous learning was also conducted through web meeting via Google Meet. There were several materials used by the teacher. Those were module, Power Point Presentation and videos from YouTube.

Since the teacher already planned learning in a certain syntax, the activities were usually started by meeting in Google Meet which was then continued with the first activity namely thinking about it in which the students started thinking about the materials given by the teacher by observing a paragraph or passage. It was later continued by learning the materials from module or videos. After learning the materials, students were invited to master the materials for example by analyzing a new paragraph and identifying the expressions used in a paragraph or dialogue. The last activity was trying to use the given material in their context like observing surrounding and make examples based on observation done by the students. There were two evaluation given by the teacher, namely a test to analyze the knowledge and assignment like making videos for the skills. In addition, it was also found that the involvement of parents in online learning was high since now the students were at home. In some conditions, the students and parents shared the same gadget so the students should wait for their parents to come back home and join online learning. Besides, it was also realized that the students also asked their parents to help them in finishing or guiding them in learning especially in understanding the materials and project. Based on the observation, the students were invited to be an active learner since the teacher gave space for them to discuss with classmates and also teacher in one of syntax stages applied by the teacher. Besides, collaborative learning also happened because in trying activity, the teacher usually asked students to make a group with their classmates and collaboratively analyze a certain case based on material given. Therefore, effective learning was planned behind the activities applied during online learning in remote learning context.

\section{The Teacher's Consistency between Cognition and Implementation of Online Learning in Remote Learning Context}

There were eight points observed for the teacher's consistency. The result showed that the teacher was consistent for all points observed in this section. In other words, there was a consistency between teacher's cognition toward online learning with the implementation of online learning in remote learning context. The teacher knew ICT very well in which he was up to date to the recent technology that could help the learning process became more attractive. Besides, the teacher had tried some different LMS before pandemic was even started which showed the knowledge of the teacher on LMS for learning. There were some gaming platforms planned by the teacher to use to make the learning fun like quizizz.com and kahoot.com. The teacher knew teleconference apps. Sometimes, He made some consideration on what app was best used in recent condition. The teacher had good ability in utilizing ICT for learning. He did not only used Laptop for conducting learning. In some moment, He switched to Smartphone and also Computer. He was also familiar with useful apps and platforms to vary the learning process. The teacher could optimize the use of learning platform during learning process. It could be seen by looking at how he managed the material and faced problems related LMS reported by students. In relation to the learning materials used by the teacher for learning, the teacher prepared some different materials including audio, video PowerPoint as well as a module. By preparing some materials, the teacher could manage the activities very well for each chapter by applying a certain syntax during online learning. In conclusion, there was a consistency between teacher's cognition toward online learning with the implementation of online learning in remote learning context.

Discussing about cognition and teaching practice, it was found that the way teacher organized their teaching practice in classroom was based on their cognition. What the teacher's belief on a certain subject gave influenced to teaching strategies and activities applied in classroom teaching (Gilje, 2014). On the observed data related to teacher's consistency between cognition and implementation of online learning in remote learning context, the researcher found that the teacher was consistent. The teacher showed consistency in all aspects observed which covered knowledge on ICT, Knowledge on LMS, Gaming platform for learning, Knowledge on teleconference apps, Ability in utilizing ICT for learning, Ability in utilizing LMS for learning, Suitable learning material for online learning and Organization of activities in online learning.

\section{Teacher's Perception toward Online Learning}

After teacher's cognition and the implementation of online learning were analyzed, perception of teacher as the one responsible for the online learning was analyzed through questionnaire which covered motivation, effectiveness, engagement, overall satisfaction and technical details. In addition, the advantages and disadvantages of online learning was also analyzed from the viewpoint of teacher. The total score got by the teacher was 83 which was then analyzed through ideal mean score and categorized 
into 3 levels in order to know the teacher's perception toward online learning in remote learning context in which those were bad, neutral or good. Based on the analysis, Xmax was the maximum score that the teacher could get if the answer was all 5 or strongly agree and the Xmin was the minimum score that the teacher could get from the questionnaire if the answer was all 1 as it referred to strongly disagree. Since there were 19 items included and it used Likert-scale point in which it was 1-5 representing strongly disagree until strongly agree at 5 point, so the possible minimum score or Xmin was 19 and the possible maximum score was 95. Range, Mean Ideal (MI) and Standard Deviation Ideal (SDI) was analyzed in order be able to categorize the teacher's perception. After the categorization was made, the next step was to figure out the teacher's perception whether it positive or negative. Since the teacher got 83, it referred to very positive because it was above 76.05 as the minimum score for very positive perception toward online learning. In other words, the teacher thought that online learning in remote learning context helped them in the process of teaching and learning. In addition, when the data were also analyzed based on each dimension including motivation, effectiveness, engagement, overall satisfaction and technical details.

Based on data analysis, it was found that generally the teacher thought that online learning promoted his motivation to teach students in remote learning context. It was also effective for learning in recent condition in which it was remote learning due to COVID-19 pandemic. The teacher felt that through online learning, teaching and learning process was more engaged. In overall satisfaction dimension, it was found that online learning gave satisfaction for teacher in teaching. Moreover, there was no problem in technical details in implementing online learning. From the questionnaire delivered, it also asked teachers in an open-ended question related to advantages and disadvantages of online learning. Based on the teacher's perception, the advantages of online learning were the material was easier to be delivered and organized. In addition, it was easy to conduct assessment. Meanwhile, for the disadvantages of online learning could be categorized into two categories since the teacher thought that online learning was challenging. The first was problem on internet connection and students' motivation. As how online learning should be, it needed internet connection which was not only fast but also stable. Then, it was hard to maintain good connection which was stable for both teacher and students. There might also possibility of costing much money for internet connection in online learning. Therefore, facility especially related to internet connection was the challenge or disadvantage in conducting online learning in remote learning context. The second disadvantage told by the teacher was related to students' motivation which was hard to build during online learning. In conclusion, the teacher thought that online learning was good for students but there were some challenges needed to be considered like internet connection and students' motivation during online learning in remote learning context.

\section{Students' Perception toward Online Learning}

In collecting students' perception toward online learning in remote learning context, there were 30 students chosen as the sample of the research. the students were given 19 statements representing several dimensions such as motivation, effectiveness, engagement, overall satisfaction and technical details. After the total score of students' perceptions was collected, it was planned to be categorized through ideal mean score analysis in order to know whether online learning was bad, neutral or good from the viewpoint of students as the participant in online learning. The Xmax was the maximum score that the teacher could get if the questionnaire was all answered with 5 points. Meanwhile, the Xmin was the minimum score. Then, the Range got from the analysis was 76, Mean Ideal (MI) was 57 and Standard Deviation Ideal (SDI) was 12.7. Based on data analysis, it discovered the minimum score for each category. Data analysis showed that from all respondents, $3.3 \%$ felt that online learning was very negative, $10 \%$ felt that online was negative, $26.7 \%$ thought that online learning was neutral. Besides, there were $46.7 \%$ thought that online learning was positive and $13.3 \%$ was very positive. The highest category was positive in which there were 14 students included. In conclusion, it was realized that some students might see online learning negatively as well as neutral. However, most of the students thought that online learning in remote learning context was positive in which it helped them to learn in pandemic situation. For more details about the percentage of each dimensions.

Based on data analysis in which it analyzed the mean of each dimension chosen by the students related to their perception towards online learning, it showed that the students were generally neutral. It was identified from the numbers of mean analyzed which were all between 3-4. Those numbers showed that the students were more than neutral, but it was not agreed since there were no numbers got 4 in its mean. In conclusion, the analyzed data meant that online learning did not give really big impact on their motivation, effectiveness, engagement, overall satisfaction and technical details because of the mean was not at least 4 which meant agree based on the questionnaire used to collect the data of students' perception toward online learning. 


\section{Parents' Perception toward Online Learning}

Besides teacher and students' perception, this research also collected data from parents in which it was also about their perception toward online learning in this remote learning context due to recent pandemic COVID-19. There were 19 items delivered. 10 parents were asked to fill the questionnaire and below was the result of the questionnaire especially for the closed-ended which applied 5-point Likertscale. The score was then analyzed through ideal mean score analysis in order to know whether online learning was positive or negative from the viewpoint of parents as the participant in online learning. The Xmax was the maximum score that the parents could get if the questionnaire was all answered with 5 points. Meanwhile, the Xmin was the minimum score. Then, the Range got from the analysis was 76, Mean Ideal (MI) was 57 and Standard Deviation Ideal (SDI) was 12.7. The result showed that $20 \%$ of parents' perception was very negative. In other words, the parents thought that online learning did not help them a lot. Besides, $20 \%$ of the teacher also chose negative and $20 \%$ neutral in which it meant $20 \%$ of them did not think that online learning could However, there were some facts that the parents told to the questionnaire in the open-ended question which would be shown on the next section. In addition, there was only $10 \%$ or 1 parents felt that online learning was good based on the questionnaire delivered. For more details about the percentage of each dimensions, below was the result of the analysis.

Based on data analysis results, it was known that the mean of each dimension was all between 2-3 in their mean. It meant that parents' perception toward online learning in remote learning were almost all under neutral since there was only one passing the neutral point in technical details dimension. Those numbers showed that the parents did not see online learning as good way of learning because they disagreed whether it gave good impact on motivation, effectiveness, engagement and the other dimension observed in this research. it was also supported by their perception in an open-ended question answered at the end of the questionnaire. There were two open-ended question delivered related to the advantages and disadvantages of online learning in remote learning context. For the advantages, some parents thought that it did not have any advantages and told many disadvantages instead of advantages of online learning. However, the others thought that through online learning, the student (their child) could be creative, motivated to learn and invited students to learn harder. In addition, the they also thought that online learning is good and safe for now especially in recent condition in which COVID-19 was everywhere. Therefore, the students could learn and still be safe from the spread of COVID-19.

Besides, different from the advantages, the parents told many things related to disadvantages of online learning in remote learning context. Some of them were their child spent much time in his room looking at the smartphone to join an online learning or even work on assignments given. As implication, their child had lack of time to help parents at home which was different from when learning was still done like the conventional one. Online learning also cost much money caused by data or internet connection for joining or working on assignments in online learning. Therefore, it gave much burden in economical part. Sometimes, when their child had internet connection, the new problem came in which the network was not stable in some area. Besides, some parents also told that their child did not understand the material very well. In addition, their child also complained that their day was full of assignments to do. In conclusion, from both advantages and disadvantages of online learning, the parents thought that online learning had many disadvantages instead of advantages in which it was also in line with the result of 5 points liker-scale which showed that most of the parents disagree on some dimensions analyzed in this research.

\section{Disscussion}

\section{Teacher's Cognition toward Online Learning in Remote Learning Context}

By having high cognition toward online learning, the teacher probably could easily deal with recent condition in which online learning was applied by the government since March 2020. It was supported by a research in which the topic discussed about the relationship between teachers knowledge, attitude and belief with the implementation of Inquiry-Based Learning (Xie et al., 2014). The study found that there was significant relationship between cognition in which knowledge, attitudes and beliefs with teachers' teaching practice. The teacher's cognition level toward subject influenced the materials prepared, strategy used and the class organized. Therefore, it revealed that when the teachers had positive or high cognition on certain subject of learning, it would also give impact to the teaching practice in classroom.

Another study also showed how cognition influenced classroom teaching. Previous study explored the teacher's cognition on reading class (Gilje, 2014). The study found that the teacher's cognition toward reading class was highly influenced by teacher education, teacher experience as student or even teachers' classroom experience in which textbooks colored their cognition, it made the reading class conducted was a textbook reading activity. This showed and supported the data found in recent 
study about how cognition influenced teaching practice. Since the teacher had high level of cognition toward online learning in which there were some aspects related to knowledge, self-efficacy and belief on ICT, gaming platform, synchronous learning apps, and LMS were observed, it constructed the probability of well-organized online learning would be done by the teacher. The finding was also supported by the theory which tells about the effect of cognition toward teacher's decision for their classroom practice (Borg, 2003). He discovers that it is teacher experience as students, teacher's education and surrounding that form teacher's cognition (knowledge, attitudes, beliefs) in which then influence teacher's decision for his teaching practice in classroom. In conclusion, high cognition level toward online learning would give good impact on the implementation in the class.

\section{The Implementation of Online Learning in Remote Learning Context}

For the implementation of online learning, there are at least four steps of preparation needed, namely deciding targeted, substantial, procedural as well as effective component (Lebedev, 2019). Then, the observed data showed that the teacher prepared all the things well. The objectives were made based on the syllabus which was developed to be the lesson plan. Selecting materials, assignments and activities as the substantial components were done carefully to meet the students' need as Gen Z students. Since online learning needed Technology competence so much, the teacher had already thought about the tools, apps which were used for online learning in this remote learning context such as the LMS used, laptop, hand phone and teleconference apps for the synchronous learning in each meeting. The evaluation was also planned in such a way so the students had portfolios as well as projects to measure the students' progress.

During the implementation of online learning, the teacher applied some steps or stages for each meeting. In other words, there were content or materials given which was given and then learnt by the students. There was an online meeting usually held by the teacher via Google meet to say hello as well as introducing the materials and guided them towards some activities to do for the meeting. Furthermore, there was a discussion section opened in Google classroom after face-to-face time and thinking activity. It was conducted in order to know students' participations during the lesson. Moreover, it also gave time for both teacher and students to share ideas towards the materials learnt.

The teacher also gave time for students to practice the knowledge learnt through some questions and things to do by their selves or collaboratively between students which were then guided them to make task, assignment and project. It was given to make them practice the knowledge they got during the lesson. In summary, there were some stages prepared by the teacher in his online learning implementation. As what is shown in Fig.3, there were four stages of online learning applied in each meeting covering Thinking about it, learn about it, Master it and Try it. This syntax was actually in line with the theory about online learning implementation. It is called The Multimodal Model which consists of six stages including Content, Social/Emotional, Questioning, Synthesis/Evaluation (Assignment/Assessment), Collaboration/Student Generated Content and Reflection (Picciano, 2009). The model is flexible as how it is called as Blending with Purposes - Multimodal Model. It means that the syntax could be adjusted based on the objective or purpose of learning. In relation to the theory, from six stages, the teacher applied all the six stages even though the terms were different.

The first stage was content or the materials as one of some important points in learning which was now could be delivered through some LMS. In this research, the teacher used Google Classroom as the space for sharing information with students. The second stage was social emotional which paid attention on supporting students socially and emotionally because learning was not only about knowledge and skills. In here, it was noted that existence of teacher was important for students to have someone to share and argue with. Therefore, face to face time was important to give motivation for students during learning process. This process was done by the teacher in his syntax through Google Meet web meeting. The next stage was questioning or discussion board. The activity was about measuring what the students know about the materials learnt. Sharing information between teacher with students and students to students were organized. This was also the time for teacher to give the right question to students in order to help students think critically about the materials or issues. This stage was done by the teacher on the first stage in his learning. The next stage was synthesis evaluation which also meant assignment and assessment. This activity was done by the teacher on the fourth stage in his learning. This was done through test, presentations, portfolio or project.

Another stage was collaborative learning in which this was on the third stages in teacher's syntax. This was about the collaboration of students in working on some tasks given by the teacher. In face-to-face learning, group work could be facilitated by the teacher so the learning could be meaningful for each participant. Meanwhile in online leaning, collaborative work between students could be done by working together in a group by utilizing recent technology which give students options like making group in 
WhatsApp and working collaboratively with the others. The last stage was reflection which was usually done by the teacher at the end of each learning session. This activity usually asked student what they got from the learning session. By analyzing the stages above, the teacher applied all the six stages from Picciano even though the terms were different.

\section{The Teacher's Consistency between Cognition and Implementation of Online Learning in Remote Learning Context}

Discussing about cognition and teaching practice, it was found that the way teacher organized their teaching practice in classroom was based on their cognition. What the teacher's belief on a certain subject gave influenced to teaching strategies and activities applied in classroom teaching (Gilje, 2014). On the observed data related to teacher's consistency between cognition and implementation of online learning in remote learning context, the researcher found that the teacher was consistent. The teacher showed consistency in all aspects observed which covered knowledge on ICT, Knowledge on LMS, Gaming platform for learning, Knowledge on teleconference apps, Ability in utilizing ICT for learning, Ability in utilizing LMS for learning, Suitable learning material for online learning and Organization of activities in online learning.

The teacher had good ability in utilizing ICT for learning. He did not only used Laptop for conducting learning. In some moments, He switched to Smartphone and also Computer. He was also familiar with useful apps and platforms to vary the learning process. This showed how the knowledge and ability of teacher in dealing with ICT. This consistency was good for the online learning because it drove to successful teaching since ICT gave various options for teacher to vary the learning process. Previous study about ICT declared the importance of ICT for education nowadays (Ghavifekr \& Rosdy, 2016). The role of ICT is vital since it is one of the main aspects in online learning. On the other aspect, for instance in organizing activities in online learning, the teacher could manage the activities very well for each chapter by applying a certain syntax during online learning. This finding is in line with the theory stating that the way teacher planned, prepared, and organize activities were influenced by the cognition itself (Borg, 2003). To conclude, the data analyzed was consistent by which it was supported by the existing research as well as the theory from Borg.

\section{Teacher's Perception toward Online Learning}

The recent situation forced education to conduct online learning in which it did not yet become a common learning process yet for education in Indonesia. Therefore, after analyzing the teacher's cognition and its implementation, the study also explored teacher's perception toward online learning in remote learning context. The finding showed the teacher had a very positive perception toward online learning. In some cases, online learning made the learning easier in parts of delivering materials and organizing learning activities because all was done through smartphone or laptop in a second even though the preparation took around a week. In addition, the teacher also stated that through online learning, assessment was easier to be conducted. The data were supported by study in which online learning gave advantages to learning process especially on delivering receiving materials (Sadeghi, 2019). Since online learning makes learning flexible, then the materials could be accessed anytime and anywhere. It eased both teacher and students by which the teacher could deliver materials at any time as long as it was ready and had internet connection. So do the students since they could access the materials anywhere as long as the students had stable internet connection.

However, the teacher also faced problems in conducting online learning. As noted above, indeed learning could be done in any condition but internet connection was a necessity. Therefore, the teacher felt that online learning was challenging when the internet was unstable especially during face-to-face online meeting via Google meet. In addition, it could cost much money caused by spending much internet connection for joining online classroom. Besides, the teacher also thought that it was challenging to build students' motivation in online learning. This was in line with study which found that there were two barriers in online learning, namely strong barriers and weak barriers (Simonson et al., 2011). The strong barriers meant strong challenge faced during the class and vice versa for the weak barriers. One of the strongest barriers was like increasing time commitment which meant online distance learning might be flexible but if it was counted, it needs extra time and concentration in order to be able to keep in touch to the materials. Besides, lack of infrastructure was also one of the strongest barriers found. Meanwhile, for the weakest barrier, technology fee and lack of parental involvement were two of them. Furthermore, problems in online learning were apparently not that simple because there was also another problems such as ineffective learning process caused by repeated questions from students (Pant, 2014). In recent condition, online learning brought both advantages and challenges for teacher. The challenges might give 
pressure but since online learning was a new strategy caused by pandemic, it should need habituation so the adjustment could be done to fix the problems.

\section{Students' Perception toward Online Learning}

There were still debate on the impact of online learning since some showed that online learning was effective while the others were not especially for students in recent pandemic situation. After analyzing teacher's perception, this study also explored how students perceived online learning as their learning method nowadays. The result showed a unique finding because indeed, the students saw online learning in a positive way in which it could help them to learn during Covid-19 situation and give them time to learn slowly because they could access the materials easily without any limitation of time. However, the students surprisingly gave many different disadvantages of online learning during recent pandemic. For instance, the problem on internet connection, unqualified smartphone, monotonous learning activities and assignment as well as unstable signal. When the questionnaire was delivered, the students enthusiastically expressed their anxiety and worries about online learning. From many different perceptions, the lists mentioned in research finding were the most frequent answers given by the students. The finding was actually in line with some studies which explored problems on the implementation of online learning. It was found that the students were happy but there were some reasons that make them choose face to face than online learning (Altunay, 2019). Those were lack of technical support and equipment for distance learning. Technical support might include internet connection, unstable signal while equipment might include facilities like laptop and smartphone. Another study found the importance of network access and qualified devices in online learning which could guide to effective and successful learning process. By relating the disadvantages with the supporting research above, it was fair that the students thought that online learning was good but not effective (Hamid et al., 2020).

\section{Parents' Perception toward Online Learning}

According to the study conducted by Rusmiati et al. (2020), there were some factors determining the successful of online learning during Covid-19 situation in Indonesia. Some of them were readiness of technology, support and collaboration with government, schools, teachers and parents. Recent study also explored parents' perception because online learning put students at home by which learning was done fully through smartphone and network access support. These changes from the traditional teaching and learning process must have made impact on parents since the students who usually learnt at school but now was at home. The change on the environment should bring some impact like their child might need an extra internet and they had more contact with smartphone for all day long for learning or making assignment. Then, from 10 parents observed, the study found that at first, it was quite balance between positive and negative perception toward online learning. However, when the data were analyzed deeper, the researcher discovered the fact that from all 5 dimensions observed, there was only one passing the neutral point in its mean and the rest was below neutral perception. In other words, the parents thought that online learning did not help their children in learning. These findings were supported also by the data in open-ended question delivered to students asking about advantages and disadvantages of online learning based on their perception.

Some of parents actually gave positive feedback in which it motivated their child to be creative in online learning. They also said that online learning was safe since it avoided their children from Covid-19 virus. However, there were many disadvantages given in this section different from the advantages which could be counted. As how the students also stated many negative perceptions, so did their parents. The parents even wrote no advantages of online learning in advantages question. They thought that online learning made their children stay for all day long in their room and focused more on smartphone. It caused them lack of time to help their parents at home. Online learning also cost much money because their child needed an extra internet data account. In other words, it gave burden in economic sector. Besides, their children also complained that since online learning was applied, the learning was monotonous and there were too much assignments. Therefore, these findings supported the data on negative perception of parents toward online learning.

The findings were also supported by existing study showing that the $83.7 \%$ of parents did not see home learning during pandemic was effective. There were some benefits mentioned but it was more disadvantages. Some of them were the challenge of keeping children motivated and new role as parent educator. Lack of internet access and devices which evoked additional costs. The parents also noted that the learning should have fewer assignments and more engagement (Abdulrahman, 2020). As a conclusion, the parents may think that online learning was good to keep their children safe form the virus but there were more complains on their perception towards online learning. 


\section{CONCLUSION}

The teacher has high cognition level toward online learning in which it eases him to organize online learning in remote learning context. The teacher also has his own syntax for teaching online learning. Moreover, the materials are also adjusted to meet students' interest. Online learning implementation is well prepared and organized because the teacher prepares various media and materials from videos, audios and modules for learning and applies certain syntax, namely think about it, learn about it, master it and try it. The teacher's cognition and online learning implementation is consistent. Besides, teacher's perception, students' perception and parents' perception are also analyzed. The result shows that the teacher perceives online learning positively with some notes of advantages and disadvantages. The students perceive online learning positively. However, the students give many responses on disadvantages over advantages of online learning. The parents' perception toward online learning is balanced between positive and negative. Some of them give advantages of online learning. However, most of them give many disadvantages of online learning in their responses.

\section{REFERENCES}

Abdulrahman, T. R. (2020). Parents' Perceptions of Children's Remote Learning during the Covid 19 Outbreak: A Case Study in Bekasi, Indonesia. Fulbright Virtual English for Graduate Studies, November. https://doi.org/10.13140/RG.2.2.33176.21760.

Afrilyasanti, R., Cahyono, B. Y., \& Astuti, U. P. (2017). Indonesian EFL Students' Perceptions on the Implementation of Flipped Classroom Model. Journal of Language Teaching and Research, 8(3), 476-484. https://doi.org/10.17507/jltr.0803.05.

Ahmadi, M. R. (2018). The Use of Technology in English Language Learning: A Literature Review. International Journal of Research in English Education (IJREE), 3(2), 115-125. http://ijreeonline.com/browse.php?a_code=A-10-25-4\&slc_lang=en\&sid=1.

Altunay, D. (2019). EFL Students' Views on Distance English Language Learning in a Public University in $\begin{array}{lllll}\text { Turkey. Studies in English Language Teaching, } & \text { 7(1), }\end{array}$ https://doi.org/10.22158/selt.v7n1p121.

Arnold-Gaza, S. (2014). The Flipped Classroom Teaching Model and Its Use for Information Literacy Instruction. Communications in Information Literacy, 8(1). https://pdxscholar.library.pdx.edu/comminfolit/vol8/iss1/9/.

Bhattacharjee, B., \& Deb, K. (2016). Role of ICT in 21st Century's Teacher Education. International Journal of Education and Information Studies, 6(1), 1-6. http://www.ripublication.com/ijeis16/ijeisv6n1_01.pdf.

Borg, S. (2003). Teacher Cognition in Language Teaching: A Review of Research on What Language Teachers Think, Know, Believe, and Do. Language Teaching, 36(2), 81-109. https://doi.org/10.1017/S0261444803001903.

Çevikbaș, M., \& Argün, Z. (2017). An Innovative Learning Model in Digital Age: Flipped Classroom. Journal of Education and Training Studies, 5(11), 189. https://doi.org/10.11114/jets.v5i11.2322.

Creswell, J. W. (2012). Educational Research: Planning, Conducting and Evaluating Quantitative and Qualitative Research. University of Nebraska-Lincoln: Pearson.

Csobanka, Z. E. (2016). The Z Generation. Acta Technologica Dubnicae, 6(2), 63-76. https://doi.org/10.1515/atd-2016-0012.

Demertzis, M., Sapir, A., Tagliapietra, S., \& Wolff, G. B. (2020). An effective economic response to the coronavirus in Europe Executive. Bruegel.

Fareed, M., \& Bilal, M. (2016). ESL Learners' Writing Skills : Problems, Factors and Suggestions ESL Learners ' Writing Skills : Problems , Factors and Suggestions Introduction. Journal of Education and Social Sciences, 4(2), 81-92. https://doi.org/10.20547/jess0421604201.

Ghavifekr, S., Kunjappan, T., \& Ramasamy, L. (2016). Teaching and Learning with ICT Tools: Issues and Challenges from Teachers' Perceptions. Malaysian Online Journal of Educational Technology, 4(2), 38-57. https://eric.ed.gov/?id=EJ1096028.

Ghavifekr, S., \& Rosdy, W. A. W. (2016). Teaching and Learning with Technology: Effectiveness of ICT Integration in Schools. International Journal of Research in Education and Science, 1(2), 175. https://doi.org/10.21890/ijres.23596.

Gilje, T. M. (2014). Teacher Cognition and The Teaching of EFL Reading in Norwegian Upper Primary Classrooms. Acta Didactica Norge, 8(2), 1-17. https://doi.org/10.5617/adno.1141.

Gustiani, S. (2020). Students' Motivation In Online Learning During Covid-19 Pandemic Era : A Case Study. Holistics Journal, 12(2), 23-40. https://jurnal.polsri.ac.id/index.php/holistic/article/view/3029. 
Habibu, T., Abdullah-Al-Mamun, M., \& Clement, C. (2012). Difficulties Faced by Teachers in Using ICT in Teaching-Learning at Technical and Higher Educational Institutions of Uganda. International Journal of Engineering Research \& Technology (IJERT), 1(7), 1-10.

Hamid, R., Sentryo, I., \& Hasan, S. (2020). Online learning and its problems in the Covid-19 emergency period. Jurnal Prima Edukasia, 8(1), 86-95. https://doi.org/10.21831/jpe.v8i1.32165.

Hernandez, R. M. (2014). Impact of ICT on Education: Challenges and Perspectives. Journal of Educational Psychology-Propositos y Representaciones, 1(4), 3-8. https://eric.ed.gov/?id=EJ1139346.

Hernandez, Ronald M. (2017). Impact of ICT on Education: Challenges and Perspectives. Propósitos y Representaciones, 5(1), 325-347. https://doi.org/10.20511/pyr2017.

Kaffash, H. R., Kargiban, Z. A., Kargiban, S. A., \& Ramezani, M. T. (2010). a Close Look in To Role of ICT in

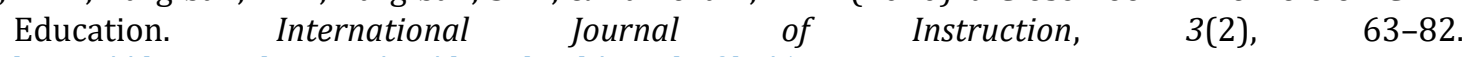
https: //dergipark.org.tr/en/download/article-file/59787.

Kristiawan, M., Aminudin, N., \& Rizki, F. (2021). Optimalisasi Pembelajaran Daring Berbasis Aplikasi Online bagi Calon Guru Pendidikan Anak Usia Dini. Jurnal Obsesi : Jurnal Pendidikan Anak Usia Dini, 5(2), 1905-1914. https://doi.org/10.31004/obsesi.v5i2.942.

Kumar, N., Rose, R. C., \& D'Silva, J. L. (2008). Teachers' Readiness to Use Technology in the Classroom: An Empirical Study. European Journal of Scientific Research, 21(4), 603-616. http://list.shaanan.ac.il/fl/files/454.pdf.

Lebedev, A. A. (2019). Individualization of Education via Distance Learning Technologies: Models, Stages, Forms and Components. International Journal of Civil Engineering and Technology, 10(1), 16311645. https: //elibrary.ru/item.asp?id=38667344.

Lin, M. H., Chen, H. C., \& Liu, K. S. (2017). A study of the effects of digital learning on learning motivation and learning outcome. Eurasia Journal of Mathematics, Science and Technology Education, 13(7), 3553-3564. https://doi.org/10.12973/eurasia.2017.00744a.

Morse, J.M; Niehaus, L. (2009). Mixed Method Design: Principles and Procedures. Walnut Creek.

Onwuegbuzie, A. J., \& Combs, J. P. (2011). Data Analysis in Mixed Research: A Primer. International Journal of Education, 3(1), 13. https://doi.org/10.5296/ije.v3i1.618.

Owens, J., Hardcastle, L., \& Richardson, B. (2009). Learning From a Distance: The Experience of Remote $\begin{array}{llll}\text { Students. Journal of Distance 23(3), } & \text { 5ducation, }\end{array}$ http://search.proquest.com.mutex.gmu.edu/docview/868262420/abstract/141A971C432349F8 $359 / 2$ ?accountid=14541.

Pankaj S. Parsania, N. M. C. \& K. C. K. (2015). Information and Communication Technology \& Its Impact in Improving the Teaching and Learning of English Language. International Journal of Computer Science Engineering and Information Technology Research (IJCSEITR), 5(3), 1-6. http://www.tjprc.org/view-archives.php?year=2015\&id=14\&jtype=2\&page=2.

Pant, A. (2014). Distance Learning : History, Problems and Solutions. Advances in Computer Science and Information Technology (ACSIT), 1(2), 65-70.

Parvin, R. H., \& Salam, S. F. (2018). The Effectiveness of Using Technology in English Language Classrooms in Government Primary Schools in Bangladesh. FIRE: Forum for International Research in Education, 2(1). https://doi.org/10.18275/fire201502011049.

Picciano, A. G. (2009). Blending With Purpose: The Multimodal Model. Research Center for Educational Technology, 13(1), 7-18. http://rcetj.org/index.php/rcetj/article/viewArticle/11.

Picciano, A. G. (2017). Theories and Frameworks for Online Education: Seeking an Integrated Model. Online Learning, 21(3), 166-190. https://doi.org/10.24059/olj.v21i3.1225.

Putri, R. S., Purwanto, A., Pramono, R., Asbari, M., Wijayanti, L. M., \& Hyun, C. C. (2020). Impact of the COVID-19 pandemic on online home learning: An explorative study of primary schools in Indonesia. International Journal of Advanced Science and Technology, 29(5), 4809-4818. https://search.bvsalud.org/global-literature-on-novel-coronavirus-2019ncov/resource/en/covidwho-830197.

Rahman, M., Karim, R., \& Byramjee, F. (2015). Prospect of Distance Learning. Journal of International Education Research, 11(3), 173-178. https://www.clutejournals.com/index.php/JIER/article/view/9368.

Rasmitadila, R., Aliyyah, R. R., Rachmadtullah, R., Samsudin, A., Syaodih, E., Nurtanto, M., \& Tambunan, A. R. S. (2020). The Perceptions of Primary School Teachers of Online Learning during the COVID-19 Pandemic Period: A Case Study in Indonesia. Journal of Ethnic and Cultural Studies, 7(2), 90. https: //doi.org/10.29333/ejecs/388.

Rasmitadila, Widyasari, Humaira, M. A., Tambunan, A. R. S., Rachmadtullah, R., \& Samsudin, A. (2020). Using blended learning approach (BLA) in inclusive education course: A study investigating teacher students' perception. International Journal of Emerging Technologies in Learning, 15(2), 
72-85. https://doi.org/10.3991/ijet.v15i02.9285.

Sadeghi, M. (2019). Limitations, A Shift from Classroom to Distance Learning: Advantages and Limitations. International Journal of Research in English Education(IJREE), 4(1), 80-88. http://ijreeonline.com/browse.php?a_id=132\&sid=1\&slc_lang=fa.

Saeed, Y. B. M. (2015). The effect of using computer technology on english language teachers ' $\begin{array}{llll}\text { performance. SUST Journal of } & \text { 64-79. }\end{array}$ http://repository.sustech.edu/handle/123456789/17005.

Santosa, M. H. (2017). Learning approaches of Indonesian EFL Gen Z students in a Flipped Learning context. Journal on English as a Foreign Language, 7(2), 183. https: //doi.org/10.23971/jefl.v7i2.689.

Schoonenboom, J., \& Johnson, R. B. (2017). How to Construct a Mixed Methods Research Design. Kolner Zeitschrift Fur Soziologie Und Sozialpsychologie, 69(2), 107-131. https://doi.org/10.1007/s11577-017-0454-1.

Simonson, M., Schlosser, C., \& Orellana, A. (2011). Distance Education Research: A Review of The Literature. Journal of Computing in Higher Education, 23(2-3), 124-142. https://doi.org/10.1007/s12528-011-9045-8.

Singh, A. P., \& Dangmei, J. (2016). Understanding The Generation Z: The Future Workforce. South -Asian Journal of Multidisciplinary Studies (SAJMS), 3(3), 1-5.

Sit, S. M., \& Brudzinski, M. R. (2017). Creation and Assessment of an Active e-Learning Introductory Geology Course. Journal of Science Education and Technology, 26(6), 629-645. https://doi.org/10.1007/s10956-017-9703-3.

Suryaman, M., Cahyono, Y., Muliansyah, D., Bustani, O., Suryani, P., Fahlevi, M., \& Munthe, A. P. (2020). COVID-19 pandemic and home online learning system: Does it affect the quality of pharmacy school learning? Systematic Reviews in Pharmacy, 11(8), 524-530. https: //search.bvsalud.org/global-literature-on-novel-coronavirus-2019ncov/resource/en/covidwho-846299.

Suryani, A. (2010). ICT in Education: Its Benefits, Difficulties and Organizational Development Issues. Jurnal Sosial Humaniora, 3(1), 106-123. http://iptek.its.ac.id/index.php/jsh/article/view/651.

Traxler, J. (2018). Distance learning-Predictions and possibilities. Education Sciences, 8(35), 1-13. https://doi.org/10.3390/educsci8010035.

Xie, M., Talin, R., \& Sharif, S. (2014). The Relationship between Teachers Knowledge, Attitude and Belief with the Implementation of Inquiry-Based Learning in Zhengzhou, China. International Journal of Learning, Teaching and Educational Research, 8(1), 149-161. http://citeseerx.ist.psu.edu/viewdoc/download?doi=10.1.1.676.9985\&rep=rep1\&type=pdf. 